\title{
СТРАТЕГИЯ РАЗВИТИЯ ЗЕРНОПРОДУКТОВОГО ПОДКОМПЛЕКСА АПК КАК ВАЖНОЕ НАПРАВЛЕНИЕ ОБЕСПЕЧЕНИЯ ПРОДОВОЛЬСТВЕННОЙ БЕЗОПАСНОСТИ СТРАНЫ "
}

\author{
(c) 2018 Зюкин Данил Алексеевич \\ кандидат экономических наук \\ Курский государственный университет \\ 305000, г. Курск, ул. Радищева, д.33 \\ E-mail: nightingale46@rambler.ru
}

В работе проводится анализ мнений российских ученых о необходимости разработки Стратегии по развитию зернопродуктового подкомплекса АПК Российской Федерации. Ученые-аграрники едины во мнении о том, что зерновое хозяйство является одним из стратегических направлений развития АПК страны. Многие считают, что разработка целевой стратегии для зернопродуктового подкомплекса АПК позволит повысить устойчивость российского зернового рынка, интенсифицировать внутреннее производство и расширить возможности развития зернового хозяйства как по части экспорта, так и по закрытию внутренних потребностей населения в продовольствии.

Ключевые слова: зернопродуктовый подкомплекс, зерновое хозяйство, стратегия долгосрочного развития, эффективность производства зерна, устойчивость зернового рынка, продовольственная безопасность.

Как отмечает группа ученых во главе с И.Г. Ушачевым [1], несмотря на успехи последних лет в развитии многих направлений отечественного АПК, не стоит надеяться, что сложившийся устойчивый тренд восходящего развития продолжится при текущих неблагоприятных макроэкономических условиях, которые не позволяют заложить основы устойчивого развития российского АПК на долгосрочную перспективу. Это, по их мнению, определяет необходимость разработки для отрасли АПК собственной стратегии социально-экономического развития на среднесрочную и долгосрочную перспективу, которая бы включала базовые цели и установки в сфере экономических отношений, предусматривала гармоничное развитие различных форм хозяйствования в АПК с учетом региональных особенностей, а также была направлена на совершенствование социальной политики и земельных отношений.

Pay B.В. [2] отмечает, что в 65 субъектах Российской Федерации условия для ведения сельскохозяйственного производства признаны неблагоприятными, что связано с осуществлением несвязанной поддержки в области растениеводства в расчете на гектар посевных площадей. Автор считает, что необходимо сформировать научно обоснованные долгосрочные меры по регулированию зернового хозяйства, как наиболее крупного и значимого сектора в АПК России, определяя главную стратегическую цель регулирования зернового хозяйства в виде устойчивого динамичного развития и повышения конкурентоспособности на мировом рынке. Для этого потребуется: увеличение доли площадей, возделываемых по интенсивным технологиям, сопряженных с комплексной программой химизации зернового хозяйства; интенсивное внедрение отечественных аналогов современных средств производства для выращивания зерна и последующих стадий его транспортировки, хранения и переработки с целью преодоления негативного влияния от западных санкций; использование потенциала по импортозамещению семенного материала по особо ценным твердым сортам пшеницы, высококачественному пивоваренному и кормовому ячменю; а также повышение регулирующей роли государства в вопросах ценовой политики и государственной поддержки и субсидирования сельскохозяйственного производства.

Анализируя итоги реализации Государственной программы «Развитие сельского хозяйства и регулирование рынков сельскохозяйственной продукции, сырья и продовольствия на 2013-2020 годы» [3] (далее Программа),

* Статья подготовлена при финансовой поддержке РФФИ в рамках научного проекта № 18-310-00211 
И.Г. Ушачев отмечает, что она постоянно корректируется, поэтому существует ежегодная неопределенность с финансированием Программы, что вызывает в условиях изначального недофинансирования необходимость выделения дополнительных средств. Это значительно снижает эффективность программно-целевого подхода к управлению АПК, подрывая уверенность сельскохозяйственных товаропроизводителей в государственные институты. Получается, что Программа в большей степени направлена на рост производства и рост объемов экспорта продукции, но при этом стабилизационные механизмы, направленные на повышение устойчивости деятельности сельхозтоваропроизводителей, предусмотрены в недостаточном количестве. Ежегодно корректирующиеся плановые темпы роста сельскохозяйственного производства значительно ниже среднемировых значений, поэтому для России важно разработать научно обоснованную Стратегию устойчивого развития АПК на 10-15 лет вперед [4].

Зерновое производство является основой сельского хозяйства Российской Федерации и наиболее распространенным направлением среди сельхозтоваропроизводителей, обеспечивая основную доходность сельскохозяйственных предприятий и служа кормовой базой для животноводства и птицеводства. Именно поэтому от производства зерна зависит продовольственная безопасность страны и эффективность реализации импортозамещения продовольствия.

В современной продовольственной корзине на долю хлебных продуктов, муки и макаронных изделий приходится максимальная величина, относительно других видов продукции. По сравнению с СССР, нормы потребления хлебной продукции в современной России возросли вдвое, в то время как нормы потребления молока, мяса, овощей и фруктов снизились от 1,5 до 4 раз по разным категориям. Это определяется неблагоприятным фактом - низким уровнем доходов населения, которые не позволяет обеспечить приобретение полноценной потребительской корзины. С другой стороны, в условиях продовольственного эмбарго и снижения общего уровня жизни населения за счет дешевых и калорийных продуктов, производимых посредством переработки зерна, легче обеспечивать население необходимым для осуществления жизнедеятельности набором калорий.

Именно поэтому мы считаем, что зернопро- дуктовый подкомплекс, учитывая его высокую значимость в обеспечении продовольственной безопасности и эффективности развития сельского хозяйства, заслуживает отдельной Стратегии, в которой будут рационально сочетаться цели и задачи самого подкомплекса и других направлений аграрного производства.

Одним из наиболее активных и авторитетных сторонников необходимости скорейшей разработки Стратегии развития российского зернопродуктового подкомплекса АПК является А.И. Алтухов. Он считает, что при разработке Стратегии развития зернопродуктового подкомплекса должно быть учтено текущее размещение и специализации сельскохозяйственного производства и предложено создание специализированных высокотехнологичных зон производства отдельных видов зерна, развития инфраструктуры и логистического обеспечения, межрегионального обмена, рационального использования производственного и биоклиматического потенциала [5].

В нашей работе мы отмечаем, что разработка собственной стратегии развития зернопродуктового подкомплекса позволит четко сформировать перспективные задачи по управлению в зависимости от наличия ресурсов и макроэкономических условий [6]. Формирование сегмента переработки зерна для потребностей внутреннего рынка на основе высоких технологий должно стать одним их стратегических ориентиров развития зернопродуктового подкомплекса. В краткосрочном периоде развитие зернопродуктового подкомплекса должно происходить путем рационализации затрат и повышении конкурентоспособности конечной продукции в контексте цены и качества [7].

В Стратегии развития зернопродуктового подкомплекса, по мнению А.И. Алтухова, должны учитываться особенности возделывания отдельных видов зерновых культур. Для этого необходимо рационально использовать аграрный потенциал территорий и повышать эффективность производства и конкурентоспособность отдельных видов зерна. В частности, целесообразно было бы сформировать территориальные кластеры зерна, в частности по производству высококачественной пшеницы, с целью удовлетворения внутренних потребностей и увеличения экспортных поставок. А.И. Алтухов считает, что их рационально разместить на юго-востоке Поволжья, в регионах Южного и 
Северо-Кавказского федеральных округов, областях Центрального Черноземья, степных районах юга Урала, Западной и Восточной Сибири, одновременно создавая недостающие объекты инфраструктуры [5].

Нами подтверждается, что подобное направление Стратегии развития зернопродуктового подкомплекса могло бы простимулировать развитие природно-экономического потенциала регионов, где зерновое производство обладает низким экспортным потенциалом, ориентируя тем самым производство на местные рынки потребления, а также может поспособствовать расширению направлений развития зернопродуктового подкомплекса, уходя от ориентации на экспорт продукции [6].

По мнению группы ученых [8] на основе зернового кластера можно разработать Стратегию эффективного управления ресурсами, которая может рассматриваться как эффективный инструмент, способствующий разработке комплексной программы, содержащей цель и задачи кластерного развития, механизмы управления кластером, конкретные целевые индикаторы, устанавливающие пороговые уровни, которых необходимо достичь при эффективном управлении имеющегося ресурсного капитала. Потенциальными участниками зернопродуктового кластера, должны выступить сельскохозяйственные организации - производители зерновой продукции, организации элеваторного комплекса, предприятия пищевой промышленности (мукомольно-крупяные, хлебопекарные, спиртовые, производители макаронных изделий и др.), которые образуют, так называемое, ядро. Внешний контур будет включать снабженческо-сбытовые, сервисные, научно-инновационные, финансовые и другие структуры, которые будут обеспечивать эффективное функционирование зернопродуктового кластера.

А.И. Алтухов и В.И. Нечаев [9] в своей монографии утверждают о несовершенстве организационно-экономического механизма зернопродуктового подкомплекса Российской Федерации. На данный момент важно, чтобы ключевая роль была отведена именно инновационной составляющая развития зернопродуктового подкомплекса. При этом ими подчеркивается главенствующую роль государства в вопросах его развития. Во многих развитых странах государство берет на себя значительную часть затрат, связанных с ускорением научно-технического прогресса, в то время как в России научно-техническая политика должным образом не разрабатывается и не реализуется. С этим согласны А.А. Маремуков и М.А. Хамукова [10], которые описывают роль государства в поддержании рыночного равновесия по отдельным видам зерна как низкую, что приводит к формированию негативной ситуации на зерновом рынке, влекущей неэффективное распределение доходов между субъектами зернового рынка и приводящей к хаотичности в развитии зернопродуктового подкомплекса.

A.C. Карайчев [11], используя SWOT-анализ зерновой отрасли, пишет о необходимости разработки взвешенной и эффективной стратегии развития зернового сектора экономики. Анализ внутренней среды сельхозпредприятий показал, что организации имеют больше слабых сторон, чем сильных. Автор предлагает при разработке стратегии и определении приоритетных целей пересмотреть машинные технологии с целью ресурсосбережения, заняться разработкой резервов и разработать инновационные проект развития потребительской кооперации в сельскохозяйственных организациях.

В коллективной монографии группа авторов [12, С. 105] раскрывают приоритетные направления инновационного развития сельскохозяйственного производства, выделяя зерно как продукт, которому следует уделять приоритетное внимание. Авторы приходят к выводу, что для этого в сфере растениеводства и защиты растений необходимо предусматривать мобилизацию, сохранение и изучение генофонда растений, создание высокопродуктивных форм растений, устойчивых к внешним неблагоприятным факторам, а также разработать системы агроэкологического мониторинга и фитосанитарного прогнозирования, используя усовершенствованные традиционные методы с использованием информационных и компьютерных технологий.

Т.И. Гуляева и О.В. Сидоренко [13] на основе бизнес-ориентированного дивизионного подхода обосновали перспективные количественные параметры отдельных сегментов зернопродуктового подкомплекса с учетом целевой установки обеспечения импортозамещения в агропродовольственной сфере. Предлагаемые ими в контексте реализации стратегии импортозамещения в агропродовольственной сфере стратегические мероприятия по развитию зернопродуктового подкомплекса целесообразно 
использовать при разработке Стратегии:

- по части зернового хозяйства: внесение изменений в базовый закон «О зерне», разработка государственной отраслевой целевой программы развития зернопродуктового подкомплекса, совершенствование структуры посевных площадей, уменьшение налоговой нагрузки на производителей и др.;

- по части переработки: реконструкция и модернизация оборудования пищевой и перерабатывающей промышленности; внедрение инновационных технологий безотходного производства, повышение эффективности использования производственных мощностей, переход организаций пищевой и перерабатывающей промышленности на новый технологический и производственный уровень и др.;

- по части хранения: строительство и реконструкция элеваторов, ориентированных на инновационные и энергосберегающие технологии;

- по части логистики: разработка информационной системы размещения мощностей по подработке, хранению и перевалке зерна, увязанной с основными товарными потоками, расширением межрегиональных связей, и интегрированной в информационную систему Минсельхоза России; применение льготных тарифов и понижающих коэффициентов для транспортировки зерна в удаленные места переработки и др.;

- по части дистрибуции: совершенствование системы закупочных интервенций на зерновом рынке, содействие выставочной и ярмарочной деятельности и др.

А.И.Алтуховым и В.И.Нечаевым выделен ряд направлений, которые, по их мнению, необходимо усовершенствовать, в целях стратегического развития зернопродуктового подкомплекса. Одним из основных они считают разработку государственной отраслевой целе- вой программы развития зернового хозяйства и зернового рынка в рамках действующей Государственной программы. Также ученые отмечают, что требуется сформировать стабильную законодательную базу для комплексного развития и зернового хозяйства и рынка зерна, усовершенствовать систему закупочных интервенций, применить систему гарантированных минимальных цен. В последние годы значительно ухудшилась эффективность функционирования мукомольно-крупяной и хлебопекарной промышленности, что произошло под влиянием территориально-отраслевого разделения труда, приведшего к ухудшению качественных показателей зерна. А также чрезмерное стремлению к экспорту негативно отражается формирование кормовой базы для животноводства и состояния почв из-за систематических нарушений в севооборотах [9].

Таким образом, исследовав мнения отечественных ученых о необходимости разработки Стратегии по развитию зернопродуктового подкомплекса в Российской Федерации, мы приходим к выводу, что, несмотря на различные подходы к обоснованию совершенствования функционирования зернопродуктового подкомплекса, ученые считают, что отдельная стратегия развития подкомплексу крайне необходима. При ее разработке стоит учесть планирование целевых показателей по развитию зернового хозяйства на среднесрочную и долгосрочную перспективу, обеспечить государственную поддержку сельскохозяйственных производителей, повысить роль государства в формировании цен на зерновом рынке, усовершенствовать организационно-экономический механизм функционирования зернопродуктового подкомплекса и использовать кластерный подход к формированию территориальных зон производства зерна, одновременно наращивая обслуживающую и перерабатывающую инфраструктуру.

\section{Библиографический список}

1. Ушачев И.Г., Серков А.Ф., Маслова В.В., Чекалин В.С. Современные тенденции и взгляд в будущее развития АПК России // АПК: Экономика, управление. 2017. № 3. С. 4-14.

2. Рау В.В. О стратегии развития зернового сектора // Проблемы прогнозирования. 2016. № 1 (154). С. $62-73$.

3. Государственная программа «Развитие сельского хозяйства и регулирование рынков сельскохозяйственной продукции, сырья и продовольствия на 2013-2020 годы» (Основные положения). [Электронный ресурс].- Режим доступа: https://refdb.ru/look/2008438-pall.html (Дата обращения: 16.11.2018 г.).

4. Ушачев И.Г., Маслова В.В., Чекалин В.С. Государственная поддержка сельского хозяйства в России: проблемы, пути их решения // АПК: Экономика, управление. 2018. № 3. С. 4-12. 
5. Алтухов А.И. Стратегия развития зернопродуктового подкомплекса - основа разработки схемы размещения и специализации зернового производства в стране // Вестник Курской государственной сельскохозяйственной академии. 2018. № 5. С. 146-152.

6. Зюкин Д.А., Солошенко Р.В., Пожидаева Н.А., Матушанская Е.Е. Обоснование необходимости стратегии развития зернопродуктового подкомплекса АПК для обеспечения продовольственной безопасности страны и комплексного развития сельского хозяйства // Вестник Курской государственной сельскохозяйственной академии. 2017. № 2. С. 60-64.

7. Зюкин Д.А. Стратегическое управление природно-экономическим потенциалом зернопродуктового подкомплекса: цели и задачи // Региональный вестник. 2017. № 1. С. 43-45.

8. Проняева Л.И., Федотенкова О.А., Павлова А.В. Формирование стратегии развития продуктового кластера в регионе // Среднерусский вестник общественных наук. 2017. № 3. С. 70-83.

9. Алтухов А.И., Нечаев В.И. Экономические проблемы инновационного развития зернопродуктового подкомплекса России: монография. Москва. 2015. 477 с.

10. Маремуков А.А., Хамукова М.А. Формирование системы устойчивого развития зернопродуктового подкомплекса КБР // Экономика и предпринимательство. 2014 . № 7 (78). С. 373-377.

11. Карайчев А.С. Разработка стратегии развития зернового производства // Теория и практика мировой науки. 2017. № 9. C. 80-82.

12. Приоритетные направления инновационного развития АПК в современной России: методологические подходы / под ред. И.С. Санду, В.И. Нечаева, Н.Е. Рыженковой. Москва 2017. 140 с.

13. Гуляева Т.И., Сидоренко О.В. Перспективные направления развития зернопродуктового подкомплекса в условиях импортозамещения // Вестник аграрной науки. 2016. № 3 (60). С. 3-9.

Поступила в редакцию 21.10.2018 